\title{
Commercial bank credit risk measurement based on KMV model studies
}

\author{
${ }^{1)}$ Chun-ping Wang ${ }^{2}$ Lin-jing Qu ${ }^{3}$ Jian-wei Li \\ ${ }^{1,2,3}$ Northwestern Polytechnical University, Xi'an, China \\ Email: 546058552@qq.com
}

Key Words: The KMV model; Commercial Banks; ST companies; The credit risk

\begin{abstract}
In this article, through selecting the KMV model in the theory of modern credit risk measurement as our country commercial bank credit risk measure, based on the 2014 commercial bank loans to customers (including 10 normal and 10 ST enterprises) of financial data and stock trading data, by measuring the sample companies default distance, then get the sample companies expected default rate, the empirical results show that the expected default rate can well reflect the credit risk of listed companies, KMV model prediction ability strong;In addition, the commercial Banks with the normal business cooperation, the lower the credit risk in the cooperation with ST enterprise credit risk is higher.
\end{abstract}

\section{Introduction}

Credit risk is the credit transaction process, since the counterparty fails to fulfill its commitments and the possibility of loss caused to the other party[1][2] . McKinsey \& Company, the actual risk of bank capital allocation as a reference, research shows th- at $60 \%$ of the total credit risk exposure to the risk of the bank, and operational risk a- nd mark- -et risk 20 percent each . Therefore, strengthening the measurement and $\mathrm{m}$ - anagement of commercial bank credit risk is particularly important .

By the end of 2014, China's commercial banks non-performing loan rate of 1.29 pe- rcent , compared with 2013 increase of 0.29 percent, the highest in 2009 to a new hi- gh , the NPL ratio continued to rise, indicating that China's commercial bank's credit risk situation is quite grim. Currently, developed countries have worked out a series of measures, credit risk management methods, and to explore suitable for China's co- mmercial bank credit risk measurement model is crucial[3][10].

As the four modern credit risk on today's international measure of KMV Models, which model data is relatively easy to obtain, the calculation process is relatively si- mple, with the promotion of the foundation in our country. Thus, compared to the other terms of the econometric model, KMV model has strong applicability in Chin- a's commercial bank credit risk metrics [5].

\section{The basic principle of KMV model}

KMV model is a default prediction model developed by the United States of KMV in 1995, it established the theoretical basis is Merton (1974) option pricing model .

\section{The basic idea of ( a ) KMV model}

Assuming that the company's capital by the bond, equity and bank loans composi- tion, and bank loans must be repaid at a predetermined time (eg one year), or will be deemed in default. If the maturity of the debt, asset value of the company is greater $t$ - han the debt level, when the company sold shares corresponding debts can get bene- fits, so the company will not default . The value of the company's assets and liabiliti- es on this level is called the default point (Default Point). 
Conversely, if the asset val- ue of the company is less than the default point, the company will choose bankruptcy instead of debt. Based on this, KMV model corporate interests as a European call op- tion, namely shareholders a liability when borrowed, equivalent to buying a compa- ny's assets as underlying assets in default point for the implementation of the price of a call option .

\section{Calculation principle (b ) KMV model}

KMV model is the theoretical basis of the Black - Scholes - Merton option pricing (BSM pricing) formula. BSM model assumptions are as follows: Securities transacti- ons are carried out continuously, transaction process does not generate transaction c- osts, risk-free interest rate is constant and remains unchanged, allowing free trading of the underlying securities, the price of the underlying securities subject to Brownian motion.

KMV model to calculate delinquencies three points : (1) The estimated value of th- e company assets and their volatility ; ( 2 ) the calculation of default and default poi- nt distance ; ( 3 ) to determine the mapping between distance to default and default $r$ - ates [11].

1) The estimated value of the assets and the volatility of the Company

The company's assets and the volatility of the equity value $\mathrm{V}_{1}$ and $\sigma_{1}$ directly obse- rvable from the market, while the market value of the assets and the volatility of $\sigma_{2}$ and $V_{2}$ can not be obtained directly, but according to Black-Scholes-Merton option pricing model, assets and market value $\mathrm{V}_{1}$ and $\mathrm{V}_{2}$ relationship exists between equity value as ( 1 ):

$V_{1}=V_{2} N\left(d_{1}\right)-D e^{-r t} N\left(d_{2}\right)$

Wherein, $\mathrm{V}_{1}$ equity market value ; $\mathrm{V}_{2}$ asset market value ; $\mathrm{D}$ for the book value of liabilities ; $\mathrm{t}$ is debt maturity ; $\mathrm{r}$ is the risk-free interest rate ; $\mathrm{N}$ (d) of the standard nor- mal cumulative probability function. For ( 1) on both sides of the derivative, and th- en seek the desired relationship between the available stock volatility and the volatile- ty of assets, such as formula (2):

$\sigma_{1}=\frac{v_{2}}{v_{1}} \mathrm{~N}\left(\mathrm{~d}_{1}\right) \sigma_{2}$

Wherein $\mathrm{d}_{1}=\frac{\ln \left(\frac{\mathrm{V}_{2}}{\mathrm{D}}\right)+\left(\mathrm{r}+\frac{1}{2} \sigma_{\mathrm{2}}^{2}\right) \mathrm{t}}{\sigma_{2} \sqrt{\mathrm{t}}}$

$\mathrm{d}_{2}=\mathrm{d}_{1}-\sigma_{2} \sqrt{t}$

Simultaneous equations ( 1 ), ( 2 ), ( 3 ), ( 4 ) you can get the value of the company's assets and the volatility of $\mathrm{V}_{2}, \sigma_{2}$.

2) Calculate the distance of default and default point

Calculate distance to default as formula ( 5 ):

$\mathrm{DD}=\frac{\mathrm{E}\left(\mathrm{V}_{2}\right)-\mathrm{DPT}}{\mathrm{v}_{2} \times \sigma_{2}}$

KMV company through a large number of empirical analysis, default occurs most frequently critical point of $50 \%$ for short-term debt plus long-term debt, which is cal- culated as DPT (6) :

$\mathrm{DPT}=\mathrm{STD}+0.5 \mathrm{LTD}$

In the above formula for the default point DPT , STD for short-term liabilities , L- TD long-term liabilities.

3) Determine the default mapping between distance and PD 
Suppose the value of assets subject to normal or lognormal probability distribution of assets , if known, the distance can be calculated by default expected default rates. W- e assume that the value of assets subject to the normal distribution, calculated theoretically expected default rates as formula ( 7 ):

$\mathrm{EDF}=\mathrm{P}\left[\mathrm{E}\left(\mathrm{V}_{2}\right) \leq \mathrm{DPT}\right]=\mathrm{N}\left[-\frac{\mathrm{E}\left(\mathrm{v}_{\mathrm{z}}\right)-\mathrm{DPT}}{\mathrm{v}_{\mathrm{z}} \times \sigma_{\mathrm{I}}}\right]=\mathrm{N}(-\mathrm{DD})$

There are some differences in the formula is based on DD deduced theoretically E- DF, EDF theory and actual default rates, But because China has not yet set up a com- plete database of corporate defaults, based on this, when China's commercial banks to measure credit risk, only to calculate the theoretical EDF.

\section{Sample Data Select}

To be able to fully reflect the general situation of various industries, paper selected customers 20 commercial banks in Shanghai and Shenzhen listed companies as resea- rch subjects, excluding containing B shares, $\mathrm{H}$ shares of listed companies, and 20 co- mpanies belong to two types : normal business, ST -share companies ( according to " listing Rules " the last two fiscal years corporate profit is negative, the net asset val- ue per share less than the par value or two fiscal years of consecutive losses of listed companies to be special treatment, namely ST process). This article will examine the chosen period January 1, 2014 - December 31, 2014, demonstration base date Decem- ber 31, 2014 [4][12].

Market transactions and financial data used in this study are from CSMAR database, the daily trading price of the annual report as well as information exchanges in Shang- hai and Shenzhen listed companies to disclose Sina Finance and all subsequent years, Each sample company's financial data as reference date are shown in Table 1 and Ta- ble 2 below[10].

Table 1 Normal operation 10 corporate financial data

\begin{tabular}{|c|c|c|c|c|c|c|}
\hline Ticker & Stock & $\begin{array}{l}\text { Total } \\
\text { equity }\end{array}$ & $\begin{array}{l}\text { base day } \\
\text { closing } \\
\text { price } \\
\quad \text { (yuan) }\end{array}$ & $\begin{array}{l}\text { Stock } \\
\text { market } \\
\text { value (Ten } \\
\text { thousand } \\
\text { yuan) }\end{array}$ & $\begin{array}{l}\text { Current } \\
\text { liabilities } \\
\text { (Ten } \\
\text { thousand } \\
\text { yuan) }\end{array}$ & $\begin{array}{l}\text { Long-term } \\
\text { liabilities } \\
\text { (Ten } \\
\text { thousand } \\
\text { yuan) }\end{array}$ \\
\hline 000713 & FENGLE SEED & 29887.6 & 10.32 & 308440.03 & 51712.83 & 2703.98 \\
\hline 000060 & Zhongjin Lingnan & 206294.09 & 9.49 & 1957730.91 & 485193.98 & 283592.21 \\
\hline 000027 & $\begin{array}{c}\text { SHENZHEN } \\
\text { ENRGY }\end{array}$ & 264299.44 & 11.16 & 2949581.75 & 1429476.93 & 379203.32 \\
\hline 000090 & Tagen Group & 55253.08 & 13.8 & 762492.50 & 625998.86 & 107060.99 \\
\hline 000099 & $\mathrm{COHC}$ & 60607.04 & 13.75 & 833346.8 & 55131.69 & 117995.12 \\
\hline 000063 & ZTE & 343754.13 & 18.06 & 6208199.59 & 6592473.2 & 1399696 \\
\hline 000026 & FIYTA A & 39276.79 & 10.4 & 408478.62 & 147838.1 & 54292.04 \\
\hline 000011 & SZPRD A & 59597.91 & 9.98 & 594787.14 & 149383.99 & 31434.35 \\
\hline 000007 & ZERO-SEVEN & 23096.54 & 14.6 & 337209.48 & 31182.04 & 1113.86 \\
\hline 000156 & WASU & 114668.09 & 24.8 & 2843768.63 & 225525.25 & 109586.79 \\
\hline
\end{tabular}


Table2 Abnormal operating 10 ST corporate financial data

\begin{tabular}{|c|c|c|c|l|l|c|}
\hline Ticker & Stock & Total equity & $\begin{array}{l}\text { base day } \\
\text { closeing } \\
\text { price } \\
(\text { yuan })\end{array}$ & $\begin{array}{l}\text { Stock } \\
\text { market } \\
\text { value } \\
\text { (Ten } \\
\text { thousand } \\
\text { yuan })\end{array}$ & $\begin{array}{l}\text { Current } \\
\text { liabilities } \\
\text { (Ten } \\
\text { thousand } \\
\text { yuan })\end{array}$ & $\begin{array}{l}\text { Long-term } \\
\text { liabilities } \\
\text { (Ten } \\
\text { thousand } \\
\text { yuan) }\end{array}$ \\
\hline 600265 & ST Jinggu & 12980 & 9.86 & 127982.8 & 40996.21 & 0 \\
\hline 000403 & ST & 27257.76 & 17.8 & 485188.13 & 61246.5 & 12269.1 \\
\hline 600644 & $\begin{array}{c}\text { *ST Electric } \\
\text { \& Chemical Inc }\end{array}$ & 53840.07 & 9.44 & 508250.26 & 99349.1 & 68202.95 \\
\hline 600145 & *ST Yilu Wanyuan & 37768.5 & 4.58 & 172979.73 & 8762.37 & 138327.64 \\
\hline 600242 & *ST & 27333.54 & 7.18 & 196254.82 & 166437.88 & 52185.51 \\
\hline 002417 & *ST Sunnada & 27000 & 8.27 & 223290 & 71221.3 & 20.21 \\
\hline 600247 & *ST Chengcheng & 33644.16 & 5.57 & 187397.97 & 79091.79 & 3371.02 \\
\hline 000711 & *ST Kingland & 16089.84 & 12.93 & 208041.63 & 51644.16 & 35900 \\
\hline 002306 & *ST Cloud Live & 80000 & 6.09 & 487200 & 53356.32 & 57867.92 \\
\hline 600539 & $*$ ST Lionhead & 23000 & 7.25 & 166750 & 18255.82 & 3748.25 \\
\hline
\end{tabular}

\section{Empirical research based on KMV Model}

\section{Setting parameters}

In order to better carry out empirical analysis, we empirical process following assu- mptions:

1) the selected sample of the company's financial statements information is true, accurate and reliable ;

2) To facilitate the study, so that the debt maturity $t=1$, using the risk-free rate pu- blished by the People's Bank Lump -year interest rate, that is $r=3 \%$;

3) Have completed 20 listed companies tradable share reform, it is the total market value equal to the product of the benchmark stock closing price of the total share capi- tal, ie equity value $=$ base day closing price $\times$ total share capital ;

4) Assuming the stock price lognormal distribution, using historical volatility esti- mation method for calculating stock price volatility;

5) It is assumed in calculating the distance to default, $\mathrm{E}\left(\mathrm{V}_{2}\right)=\mathrm{V}_{2}$, so $\mathrm{DD}=\frac{\mathrm{V}_{2}-\mathrm{DPT}}{\mathrm{v}_{2} \times \sigma_{2}}$ 。

\section{Empirical Process}

\section{Calculation of volatility in the equity value}

We use the stock of volatility to calculate the equity value of volatility, and volatil- ity of stock price changes by amplitude (ANOVA ) to give. Day volatility ( standard deviation today ) is calculated as follows : 
$\theta_{\mathrm{i}}=\ln \left(\frac{\mathrm{s}_{\mathrm{i}}}{\mathrm{s}_{\mathrm{i}-1}}\right)$

$\sigma_{\mu}=\sqrt{\frac{1}{n-1} \sum_{i=1}^{n}\left(\theta_{i}-\bar{\theta}\right)^{2}}$

Wherein, $\theta_{\mathrm{i}}$ to stock daily return; $\theta^{-}$of the average of $\theta_{\mathrm{i}} ; \mathrm{S}_{\mathrm{i}}$ as the underlying stock closing price of the i-th day ; $S_{-}(\mathrm{i}-1)$ for the i-1 stock first day closing price ; $\sigma \mu$ as t- he underlying stock Day volatility ; $\mathrm{n}$ is the number of trading days in a year. In addi- tion, the relationship between daily stock return volatility and earnings volatility as in the formula (10)

$\sigma_{1}=\sigma_{\mu} \times \sqrt{\mathrm{N}}$

Where, $\mathrm{N}$ is the number of trading days of the year , $\sigma_{-} 1$ annual volatility of the $\mathrm{u}$ - nderlying stock . Each sample transactions on behalf of the company January 1, 2014 to December 31, 2014 into the calculation, the availability of the company's equity v- alue for each sample volatility as shown in Table 3 .

Calculate the value of corporate assets and the volatility

Simultaneous equations ( 1 ), ( 2 ), ( 3 ), ( 4 ), and the use of Matlab software for pro- gramming computer, you can get the value of each sample of the company's assets and the asset value volatility V_2 $\sigma \_2$ as shown in Table 3 .

\section{Breach of contract and breach position calculation distance}

According to the formula (6), combined with Table 1, Table 2 in the data, calcul- te the normal 10 enterprises and 10 enterprises in default position ST as shown in Table 4 .

Simultaneous equations ( 5) and (6) above, calculated according to the value of co-rporate assets and the volatility of each sample can be obtained from the company's liquidated as shown in Table 4 .

\section{EDF is expected default rate calculation}

According to the formula (7) can be obtained EDF $=\mathrm{N}[-\mathrm{DD}]=[1-\mathrm{N}(\mathrm{DD})] \times 100 \%$, can be obtained for each sample companies expected default rate as shown in Table 4 . 
Table 3 The volatility of the equity value of 20 listed companies, enterprise asset value and volatility

\begin{tabular}{|c|c|c|c|c|}
\hline Ticker & Stock & $\begin{array}{l}\text { Equity value } \\
\text { volatility } \sigma_{1}\end{array}$ & $\begin{array}{l}\text { Enterprise asset value } \\
V_{2}(\text { Ten thousand yuan })\end{array}$ & $\begin{array}{l}\text { Asset value } \\
\text { volatility } \\
\qquad \sigma_{2}\end{array}$ \\
\hline 000713 & FENGLE SEED & 0.224 & 361248.580 & 0.191 \\
\hline 000060 & Zhongjin Lingnan & 0.402 & 2703795.713 & 0.291 \\
\hline 000027 & SHENZHEN ENRGY & 0.323 & 4704807.358 & 0.202 \\
\hline 000090 & Tagen Group & 0.3 & 1473887.123 & 0.155 \\
\hline 000099 & $\mathrm{COHC}$ & 0.358 & 1001356.940 & 0.298 \\
\hline 000063 & ZTE & 0.28 & 13964164.220 & 0.124 \\
\hline 000026 & FIYTA A & 0.291 & 604634.913 & 0.197 \\
\hline 000011 & SZPRD A & 0.333 & 770261.490 & 0.257 \\
\hline 000007 & ZERO-SEVEN & 0.325 & 368550.892 & 0.297 \\
\hline 000156 & WASU & 0.251 & 3168677.702 & 0.164 \\
\hline 600265 & ST Jinggu & 0.279 & 167767.389 & 0.213 \\
\hline 000403 & $\begin{array}{c}\text { ST Biopharmaceutical \& } \\
\text { Chemical Inc }\end{array}$ & 0.352 & 556531.016 & 0.307 \\
\hline 600644 & *ST Electric Power & 0.326 & 670850.399 & 0.247 \\
\hline 600145 & *ST Yilu Wanyuan & 0.392 & 315721.377 & 0.215 \\
\hline 600242 & *ST Zhongchang & 0.383 & 408414.413 & 0.184 \\
\hline 002417 & *ST Sunnada & 0.391 & 292426 & 0.299 \\
\hline 600247 & *ST Chengcheng & 0.34 & 267423.639 & 0.238 \\
\hline 000711 & *ST Kingland & 0.392 & 292998.451 & 0.278 \\
\hline 002306 & *STCloud Live & 0.49 & 595136.853 & 0.401 \\
\hline 600539 & *ST Lionhead & 0.347 & 188103.751 & 0.308 \\
\hline
\end{tabular}


Table4 20 listed companies in breach position, distance to default and expected default rate

\begin{tabular}{|l|c|c|c|c|}
\hline Ticker & Stock & $\begin{array}{c}\text { Default position } \\
\text { DPT (Ten } \\
\text { thousand yuan) }\end{array}$ & $\begin{array}{c}\text { Distance to } \\
\text { Default } \\
\text { DD }\end{array}$ & $\begin{array}{c}\text { Expected } \\
\text { default rate } \\
\text { EDF }\end{array}$ \\
\hline 000713 & FENGLE SEED & 53064.82 & 4.461 & 0.00041 \\
\hline 000060 & Zhongjin Lingnan & 626990.085 & 2.639 & 0.41593 \\
\hline 000027 & SHENZHEN ENRGY & 1619078.59 & 3.239 & 0.06 \\
\hline 000090 & Tagen Group & 679529.355 & 3.473 & 0.02577 \\
\hline 000099 & COHC & 114129.25 & 2.974 & 0.14702 \\
\hline 000063 & ZTE & 7292321.2 & 3.838 & 0.00620 \\
\hline 000026 & FIYTA A & 174984.12 & 3.615 & 0.01504 \\
\hline 000011 & SZPRD A & 165101.165 & 3.055 & 0.11239 \\
\hline 000007 & ZERO-SEVEN & 31738.97 & 3.073 & 0.10585 \\
\hline 000156 & WASU & 280318.645 & 3.193 & 0.10342 \\
\hline 600265 & ST Jinggu & 40996.21 & 3.550 & 0.01924 \\
\hline 000403 & ST Biopharmaceutical \& & 67381.05 & 2.864 & 0.20909 \\
\hline 600644 & *ST Electric Power & 133450.575 & 3.243 & 0.05905 \\
\hline 600145 & $*$ ST Yilu Wanyuan & 77926.19 & 3.507 & 0.02269 \\
\hline 600242 & $*$ ST Zhongchang & 192530.635 & 2.872 & 0.20411 \\
\hline 002417 & $*$ ST Sunnada & 71231.405 & 2.534 & 0.56458 \\
\hline 600247 & $*$ ST Chengcheng & 80777.3 & 2.929 & 0.16982 \\
\hline 000711 & $*$ ST Kingland. & 69594.16 & 2.739 & 0.30776 \\
\hline 002306 & $*$ STCloud Live & 82290.28 & 2.148 & 1.58474 \\
\hline 600539 & $*$ ST Lionhead & 20129.945 & 2.903 & 0.18481 \\
\hline
\end{tabular}

For a more intuitive observation comparison of normal business and corporate def- ault distance ST expected default rates, the data in Table 4 we plotted a graph form shown in Figure 2 .

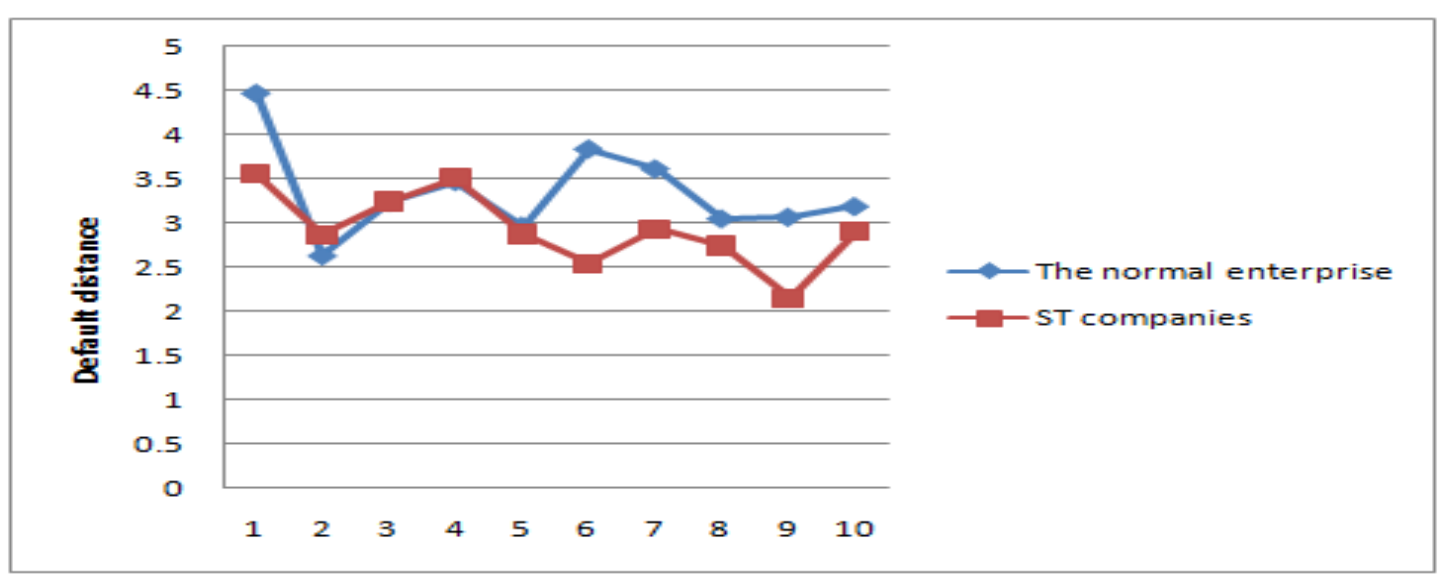

Fig.1 ST breach of normal business and enterprise distance curve 
From Fig. 1 , curve comparison of Figure 2 can be found from the most normal co- rporate defaults are higher than ST companies, expected default rates are lower than ST companies. This shows that compared to the normal enterprises, greater default pr- obability ST companies . China's commercial banks, there is a greater risk of credit cooperation between enterprises and ST .

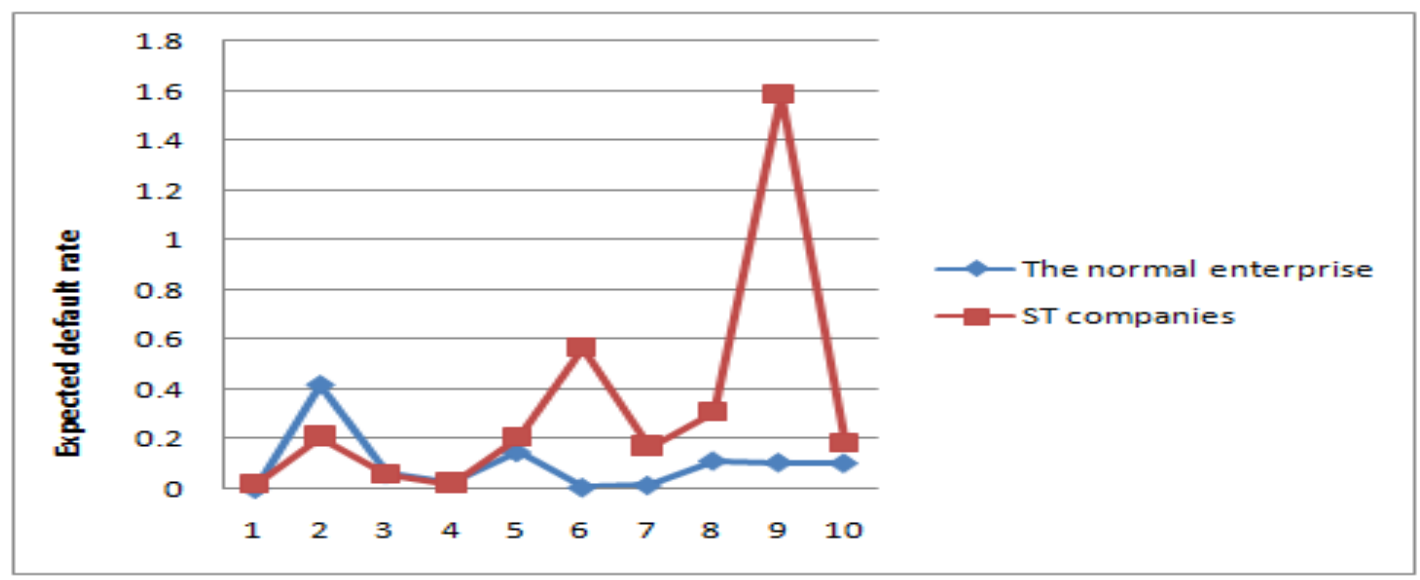

Fig.2 Expected default frequency curve of normal business and ST companies

(1) From the $E D F=[1-N(D D)] \times 100 \%$, but $D D=\frac{v_{z}-D P T}{V_{n} \times \sigma_{2}}$. We know EDF is expected default rate changes in business was mainly influenced by the volatility of assets, liabilities and equity volatility levels .

(2) As can be seen from Table 3 , the volatility of the equity value is greater than t- he volatility of the asset value, because the value of assets and liabilities included the equity value, while liabilities are greater than zero.

(3) Compared to normal business, ST corporate default rates expected higher def- ault risk is relatively large, it is mainly because, ST corporate financing channels n- arrow, financial guarantee less forceful and related financial management mechanis- $m$ is not mature, so , for China's commercial banks, ST corporate credibility is low.

(4) ST for the measure in the enterprise and the normal corporate credit risk situate- ion, also confirmed the modern credit risk measurement KMV model theory al- -so applies to our country , there is need to further improve our credit risk assessment sy- stem in order for the credit risk of commercial banks metrics provide more extensive data.

\section{Conclusions and policy recommendations}

\section{The research conclusion}

This paper starts from the concept of commercial bank credit risk, committed to the bank credit risk measurement study, chose the KMV model based on option pricing t- heory to carry on the empirical analysis, and selects 10 normal and $10 \mathrm{ST}$ enterprise financeial data and stock price time series to calculate the default distance and expec- ted default rate of listed companies. The research shows that the higher the expected default rate, the greater the credit risk.And through the default distance curve contras- $t$, we complets the risk measurement, risk measurement results confirmed that coope- ration with ST credit enterprise really can bring bigger risk to commercial banks, by contrast, commercial bank cooperated with the normal enterprise has higher credibil- ity[6].

At the same time, from the empirical results we can see, the probability of default can measure the quality of the bank credit risk that shows KMV model has certain ap- plicability in our country. 


\section{Policy Suggestions}

Along with our country securities market gradually mature and enterprises gradua- lly realize the information disclosure system, KMV model will have a broader appli- cation prospect.For the further development of KMV model and to improve the state of our country commercial bank credit risk measurement, this paper gives the followi- ng Suggestions:

Establish a default database, build the mapping between default distance DD and e- xpected default rate EDF.The missing of the default data is a large defect in the field of commercial bank credit risk measurement, because of industry habits and historical reasons, our country commercial bank don't share the information between customers, especially for the poor quality of credit customers, it will lead to the same customer c- redit risk repeat between commercial Banks. The KMV model need nearly a decade of default data to build a mapping between the default distance with the expected default rate.To this end, China's commercial Banks should set out to build a large default dat- abase, to build the data basis of mapping relationship between DD and EDF[8].

Improve the quality of customer credit, implement the loan portfolio and differenti- al pricing strategy.On one hand, Banks should establish the target market according to enterprise's development potential and anti-risk ability and target customers, thro- ugh the way of loan currency, credit collocation to establish an effective portfolio, in order to achieve the benefits given under the minimum or the established risk under the lar- gest gains. On the other hand, Banks should determine the different asset prices according to different credit rating of the enterprise within the scope of the loan[9].

Establish a professional and high level of risk management team,.Because of Chi- na's commercial Banks in credit risk measurement is still in its infancy, and modern credit risk measurement model is relatively complex, to establish a professional talent team to analyze. predict credit risk is particularly important.At the same time, we sho- uld step up risk management personnel selection and training, with high salary syste- $m$ to attract risk management talents, in addition, to strengthen the exchange and stu- dy of the members of both at home and abroad, in order to improve the team's risk m- anagement level.

\section{Reference}

[1] Brunnermeier, M.K., 2009. Deciphering the liquidity and credit crunch 2007-200 8.Journal of Economic Perspectives 23, 77-100.

[2] Carbó-Valverde, S., Degryse, H., Rodriguez-Fernandez, F., 2011. Lending Relati- onships and Credit Rationing: The Impact of Securitization. Working Paper, Tilburg University.

[3] Greenspan, A., 1998. The Role of Capital in Optimal Banking Supervision and

Regulation. In: Proceedings of a Conference on Financial Services at the Crossroads: Capital Regulation in the Twenty-First Century. Federal Reserve Bank of New York Economic Policy Review 4 (3):161-168.

[4] Gropp, R., Vesala, J., 2004. Deposit Insurance, Moral Hazard and Market Monitoring.European Central Bank Working Paper No. 302.

[5] Benston, G., 1986. Perspectives on Safe and Sound Banking: Past, Present and Future(MIT Press Series in Artificial Intelligence). MIT Press, Cambridge, MA. [6] Brunnermeier, M.K., 2009. Deciphering the liquidity and credit crunch 2007-200 8.Journal of Economic Perspectives 23, 77-100.

[7] Credit Suisse, 1997. Creditrisk+: A Credit Risk Management Framework. Credit

Suisse Financial Products.Crouhy, M., Galai, D., Mark, R., 2000. A comparative ana- lysis of current credit riskmodels. Journal of Banking \& Finance 24, 59-117. 
[8] Deelstra, G., Parker, G., 1995. A covariance equivalent discretisation of the CIR Model. In: Proceedings of the 5th AFIR International Colloquium, pp. 731-747.

[9] Slangen, A. H., \& Hennart, J. F. (2008). Do multinationals really prefer to enter culturally distant countries through greenfields rather than through acquisitions The $\mathrm{r}$ - ole of parent experience and subsidiary autonomy. Journal of International Business

Studies, 39(3), 472-490.

[10] Smith, L. D., \& Lawrence, E. (1995). Forecasting losses on liquidating long-term loan portfolio. Journal of Banking \& Finance, 19(6), 959-985.

[11] Sommerville, R. A., \& Taffler, R. J. (1995). Banker judgement versus formal for- ecasting models: The case of country risk assessment. Journal of Banking \& Finance, 19(2),281-297.

[12] Tallman, S., \& Li, J. (1996). Effect of international diversity and product divers- ity on the performance of multinational firms. Academy of Management Journal, 39 (1), 179-196. 